Volume 5, Issue 2

September 2012

\title{
American Telefantasy: An Introduction
}

\author{
SOPHIE HALLIDAY \& RHYS OWAIN THOMAS, University of East Anglia
}

Television schedules are rife with Science Fiction, Fantasy and Horror. The re-launched Doctor Who (1963-1989, 2005- ) and its prime-time Saturday night stablemate, Merlin (2008) spearhead the rise of contemporary British Telefantasy (Being Human (2008-), Misfits (2009- ) et al.). Meanwhile, their American equivalents attract audiences of millions, extensive media attention and, since Peter Dinklage's Emmy and Golden Globe-winning performance in Game of Thrones (2011- ), widespread critical acclaim through mainstream industry awards. Histories of "quality" television are awash with examples of American Telefantasy that have left an indelible impression on popular cultural (and even sociopolitical) imaginaries; Star Trek (1966-1969), The X-Files (1993-2002), Buffy the Vampire Slayer (1997-2003), Lost (2004-2010), and Battlestar Galactica (2003-2009) all being enduringly popular examples. As American television networks prepare to launch their allimportant "Fall" schedules, ushering in a new year of programming, it is evident that Telefantasy will continue to garner its fair share of TV viewers' attention - whether due to hotly-anticipated debuts (666 Park Avenue (2012- ), Arrow (2012- ), The Neighbors (2012- ), Revolution (2012- )), finales (Fringe (2008- )), provocative content (American Horror Story (2011- ), True Blood (2008- ), The Walking Dead (2010- ), or a general capacity to entertain, bewitch or amuse (Community (2009- ), Falling Skies (2011- ), Grimm (2011- ), Once Upon a Time (2011- ), Supernatural (2005- )).

Plainly, that's quite a roster of different (and differing) programmes, and we acknowledge that, by no means, does this issue of Networking Knowledge purport to cover all these texts and, quite definitely, not everything that could be considered American Telefantasy. Each contribution, rather, concentrates on a key text, figure or event that, in some way, falls within the category as it is commonly perceived; "American Telefantasy" being a term that is, undoubtedly, easier to comprehend than it is to define.

The concept of what is meant, or evoked, by the term "American" would, itself, require a lengthy analysis that is well beyond the scope of this issue. However, for current purposes, it is assumed that the term embraces certain ideals that are manifest in American national and individual identities. Most pertinently for the concerns addressed in the following articles, Tristram Riley-Smith has interrogated what he considers to be a gap between a contemporary 'American Crisis' and the American Dream (Riley-Smith, 2010). America's continued preoccupation with the question of whether it is an imperialist or hegemonic nation, he argues, seemingly indicates a need for America to make sense of its place in the world (Ibid., 209). Historically, America has long conceived of itself as a city upon a hill, to be watched by the world. ${ }^{1}$ The sense of divine mission that marked America's foundation also played an 
important role in its symbolic status as a new beginning for the world. Such ideals have continually manifested within American political culture, with French aristocrat Alexis de Tocqueville famously referring to America as an exceptional nation (Tocqueville, 2003 $[1835,1840])$. America's emphasis on 'newness,' and its enduring belief that it is different to the rest of the world, may also be seen as indicative of a national orientation towards the future; a nation frequently able to portray itself as starting anew. This inclination is still prevalent in contemporary political culture, evident in the rhetoric of President Barack Obama's inaugural address, which also explicitly recalls several of America's founding myths in its reaffirmation of America's national greatness and youth:

The time has come to reaffirm our enduring spirit; to choose our better history; to carry forward that precious gift, that noble idea, passed on from generation to generation: the God-given promise that all are equal, all are free, and all deserve a chance to pursue their full measure of happiness.' (Obama, 2009)

Yet contemporary America also finds itself in an uncertain context, marked by a period of trauma, anxiety and uncertainty. The prevalence of these contemporary anxieties presented and represented in examples of television Science Fiction, Fantasy and Horror, indicates this may be an opportune time to consider how American Telefantasy might be understood, examined and contextualised; thus, the contributions featured in this special issue of Networking Knowledge seek to engage with this by means of a multitude of intriguing approaches.

Similarly to how the term "American" may, at one and the same time, be construed as specific and indistinct, dependent on how it is employed (and by whom), "Telefantasy" is varyingly understood as being precise, vague, practical, inadequate, valuable or meaningless. In the same way, problems of definition frequently occur when the terms Science Fiction, Fantasy and Horror are used to denote intrinsic generic coherence. Whilst Darko Suvin's influential conceptualising of Science Fiction as a literature of 'cognitive estrangement' continues to cast an indelible shadow over most academic attempts to engage with that particular genre (seemingly regardless of medium), the associated genres of Fantasy and Horror - irrespective of the lack of 'cognition' inherent in their estranging narratives - are often carelessly subsumed within it; "Science Fiction" often being used as an umbrella term for "unreal" stories. However, attempts have also been made to reconceptualise perceived generic boundaries and theorise new approaches to the closely-affiliated yet professedly separate classifications of Science Fiction, Fantasy and Horror. Originally appropriated from fan communities, Catherine Johnson's term "Telefantasy" is robust enough to comfortably accommodate TV texts belonging to all three of these genres, whilst still maintaining its own recognisable, inherent integrity. It also does so without necessarily excluding other texts which may not, at first, appear to belong to the more prescriptive generic groupings of Science Fiction, Fantasy and Horror, but which contain elements of "unreality," nonetheless. 
Volume 5, Issue 2

September 2012

Because of its capacity to embrace a variety of "unreal" texts, and its provocatively nebulous quality, we consider "Telefantasy" to be an effective term for stimulating contemplation and debate, providing our intrepid contributors with a suitably expansive "universe" to explore, chart and chronicle.

The articles published herein are appropriately wide-ranging in their themes, methodologies and temporal focus, and it seems apposite to order them chronologically, thereby generating a fittingly futuristic trajectory. Accordingly, Derek Johnston opens with an overview of Telefantasy's early history; specifically, the way in which, during its formative years, the British television channel ITV embraced the "spectacular" entertainment afforded by American Telefantasy as part of its attempt to forge its own identity, and mark its differentiation from the BBC.

Of course, no study of American Telefantasy would be complete without a consideration of, arguably, the most influential and enduring example: Star Trek. This special issue of Networking Knowledge features two articles about the legendary show, both of which provide provocative revaluations of the original 1960s programme, and the franchise it spawned. Stefan Rabitsch takes issue with the commonly-held assumption that the show represents a simple re-articulation of the contemporaneous TV Western, transposing the action from the Wild West to Outer Space. Rabitsch argues that the entire franchise actually owes a greater debt to British maritime fiction, notably through its depictions of the Starfleet Captains, all of whom represent variations on C.S. Forester's sea-faring 'fighting naturalist,' Horatio Hornblower. Michael Kmet then argues for a reassessment of Gene Roddenberry's importance to Star Trek history. Whilst undoubtedly a significant agent in the creation of the original show and the resulting Trek "industry," Kmet maintains that Roddenberry's status as a "visionary" writer-producer, and Star Trek's primary author, has been distorted and exaggerated - not least by Roddenberry himself.

This sense of critical engagement is maintained by Steven John Gil, who uses 90s phenomenon The X-Files to examine the composite nature of the term "Telefantasy", employing historical examples of fantastic narratives to question the value of a term often accused of being so inherently indiscriminate that it lays itself open to misuse and misapplication.

The second half of this special issue brings us up to date with contemporary American Telefantasy. Charlotte Howell addresses the ways in which the female protagonists in Dollhouse (2009-2010) and Fringe exemplify a particularly (post)modern concern regarding personal subjectivities and fractured identities, discovering potentially optimistic outcomes in the midst of highly gendered, morally ambiguous narratives.

Tully Barnett and Ben Kooyman's article on the sitcom Community highlights the varied research possibilities afforded by the flexible generic borderlines of Telefantasy. Barnett and Kooyman argue that the programme is as much a product of fandom as it is a show about fandom, investigating its consistent use of Telefantasy tropes to provide an astute and 
Volume 5, Issue 2

September 2012

insightful commentary on "real" life, and the value of fandom. Yet if Community's loveable fanboy, Abed, represents Telefantasy at its most endearingly approachable, then American Horror Story's 'Rubber Man' may very well exemplify its most unnerving qualities. Tosha Taylor examines how the programme engenders a tangible sense of unease by drawing on fears of alternative, aberrant and "abject" sexualities as much as it does on tropes and imagery associated with the Horror genre.

Finally, keeping with the theme of costuming (though dispensing with the sadomasochistic associations), Manjree Khajanchi surveys the use of dress in recent American Telefantasy. Khajanchi argues that the conceptual use of dressing (and undressing) contributes to the metaphorical, as well as the literal, fashioning of these programmes.

Together, the articles gathered here provide a glimpse of the fascinating possibilities inherent in the study of Telefantasy, as well as within the text themselves.

\section{Acknowledgements}

The editors wish to thank Networking Knowledge's general editor, Tom Phillips, for his kind invitation to guest-edit this issue and his valuable counsel during the editing process. We'd also like to thank the peer reviewers who offered invaluable guidance to the contributors. Finally, we thank the authors themselves for devoting their time to this project so freely, their amenability to suggested changes, and for contributing such stimulating and inspiring research.

\section{References}

Johnson, C. (2005) Telefantasy. London: BFI Publishing.

Obama, B. H. (2009) Inaugural Address.

http://americanrhetoric.com/speeches/barackobama/barackobamainauguraladdress.htm [Accessed 2012, September 9]

Riley-Smith, T. (2010) The Cracked Bell: American at the Afflictions of Liberty. London: Constable.

Suvin, D. (1979) Metamorphoses of Science Fiction: On the Poetics and History of a Literary Genre. New Haven: Yale University Press.

Tocqueville, A. de (2003, [1835, 1840]) Democracy in America. London: Penguin Classics, 2003.

Winthrop, J. (1630) A Modell of Christian Charity. Available at http://history.hanover.edu/texts/winthmod.html [Accessed 2012, September 9]. 
Volume 5, Issue 2

September 2012

\section{Teleography}

666 Park Avenue. (2012- ) U.S.A.: Warner Bros. Television/Alloy Entertainment.

American Horror Story. (2011- ) U.S.A.: $20^{\text {th }}$ Century Fox Television.

Battlestar Galactica. (2003-2009) U.S.A./U.K./Canada: U.S.A. Cable Entertainment/British Sky Broadcasting/NBC Universal Television/R\&D TV/David Eick Productions/Universal Media Studios/Stanford Pictures.

Being Human. (2008- ) U.K.: Touchpaper Television.

Buffy the Vampire Slayer. (1997-2003) U.S.A.: Sandollar Television/Kuzui

Enterprises/Mutant Enemy/20th Century Fox Television.

Community. (2009- ) U.S.A.: Sony Pictures Television/Krasnoff Foster

Productions/Universal Media Studios (UMS)/Harmonius Claptrap/Russo Brothers.

Doctor Who. (1963-1989) U.K.: British Broadcasting Corporation.

Doctor Who. (2005- ) U.K./Canada: British Broadcasting Corporation/Canadian Broadcasting Corporation.

Dollhouse. (2009-2010) U.S.A.: $20^{\text {th }}$ Century Fox Television/Boston Diva Productions.

Falling Skies. (2011- ) U.S.A./Canada: Dreamworks Television/Invasion Productions.

Fringe. (2008- ) U.S.A./Canada.: Warner Bros. Television/Bad Robot/Fringe Element Films/FB2 Films.

Game of Thrones. (2011- ) U.S.A./U.K.: Home Box Office/Grok! Television/Generator Entertainment/Television 360/Bighead Littlehead.

Lost. (2004-2010) U.S.A.: Bad Robot/Touchstone Television/ABC Studios/Grass Skirt Productions.

Merlin. (2008- ) U.K.: BBC Wales/Shine.

Misfits. (2009- ) U.K.: Clarkenwell Films.

The Neighbors. (2012- ) U.S.A.: ABC Studios/Kapital Entertainment.

Once Upon a Time. (2011- ) U.S.A.: ABC Studios/Kitsis\Horowitz.

Revolution. (2012- ) U.S.A.: Warner Bros. Television/Bad Robot.

True Blood. (2008- ) U.S.A.: Home Box Office/Your Face Goes Here Entertainment.

The Walking Dead. (2010- ) U.S.A.: American Movie Classics/Darkwoods

Productions/Circle of Confusion/Valhalla Entertainment/AMC Studios.

The X-Files. (1993-2002) U.S.A./Canada: 20th Century Fox Television/Ten Thirteen Productions/X-F Productions. 
N

Volume 5, Issue 2

September 2012

\footnotetext{
${ }^{1}$ John Winthrop stated: 'For wee must consider that wee shall be as a citty upon a hill. The eies of all people are uppon us' (Winthrop, 1630).
} 